\title{
Water quality assessment based on microbiological parameter indicators for drinking water criteria on the Wadaslintang Reservoir
}

\author{
Diana R. U. S. Rahayu ${ }^{12}$, Sutrisno Anggoro ${ }^{3}$, Tri R. Soeprobowati ${ }^{45^{*}}$ \\ ${ }^{1}$ Faculty of Biology, University of Jenderal Soedirman, Purwokerto, Indonesia \\ ${ }^{2}$ Environmental Science, Diponegoro University, Semarang, Indonesia \\ ${ }^{3}$ Faculty of Fisheries and Marine Sciences, Diponegoro University, Semarang Indonesia, \\ ${ }^{4}$ Department of Biology, Faculty of Science and Mathematics, Diponegoro University, \\ Semarang, Indonesia \\ ${ }^{5}$ School of Postgraduate Studies, Diponegoro University, Semarang, Indonesia.
}

\begin{abstract}
Wadaslintang Reservoir has potential as a source of raw water for drinking water. One indicator to determine water quality is to use coliform bacteria. The purpose of this study is to determine the water quality of the Wadaslintang Reservoir as a source of drinking water based on microbiological parameters by referring to Government Regulation of the Republic of Indonesia Number 82 of 2001 concerning water quality management and water pollution control. The water sampling method is based on purposive sampling at ten research stations for eight months, microbiological analysis using the Most Probable Number (MPN) method. The results showed that the status of the Wadaslintang Reservoir was polluted based on total coliform criteria. Utilization of reservoir water as raw water for drinking water needs to be done further processing to anticipate deterioration in health.
\end{abstract}

\section{Introduction}

The Water is the source of life for all living things, therefore its existence needs to be managed properly. The water needed is clean, free of contamination and in sufficient quantities continuously. This has become the sixth goal of the Sustainable Development Goals (SDGs 2030), which is to ensure the availability and management of sustainable clean water and sanitation for all. One of the water resources used to meet the needs of the community and has a very important role for the surrounding community is the Wadaslintang Reservoir. This water resource has several functions including for agricultural irrigation, electricity generation, aquaculture and capture fisheries activities, and also used as a source of raw water for drinking water. Given the large role of these water resources, good management is needed.

\footnotetext{
* Corresponding author: trsoeprobowati@live.undip.ac.id
} 
Some previous studies show Wadaslintang Reservoir is polluted [3]. One indicator of pollution can be known based on microbiological indicators, because water is a natural habitat of microorganisms [4].

Water resources that meet the criteria for drinking water raw water begin to decrease along with the increase in antrophogenic activity that produces waste. In general, waste will be channeled into waters which will eventually lead to broader waters such as lakes, seas and reservoirs, resulting in reservoirs being polluted. One of the criteria for polluted waters can be determined based on microbiological values. The purpose of this study was to determine the status of the Wadaslintang Reservoir based on total coliform and fecal coli by referring to the quality standards of the Republic of Indonesia Government Regulation number 82 of 2001 according to drinking water criteria (class 1 and class 2)

\section{Methods}

Sampling is carried out in May - Desember 2017 in the Wadaslintang Reservoir, Wonosobo Regency. The method used in this study is a survey method with water sampling techniques using purposive sampling.
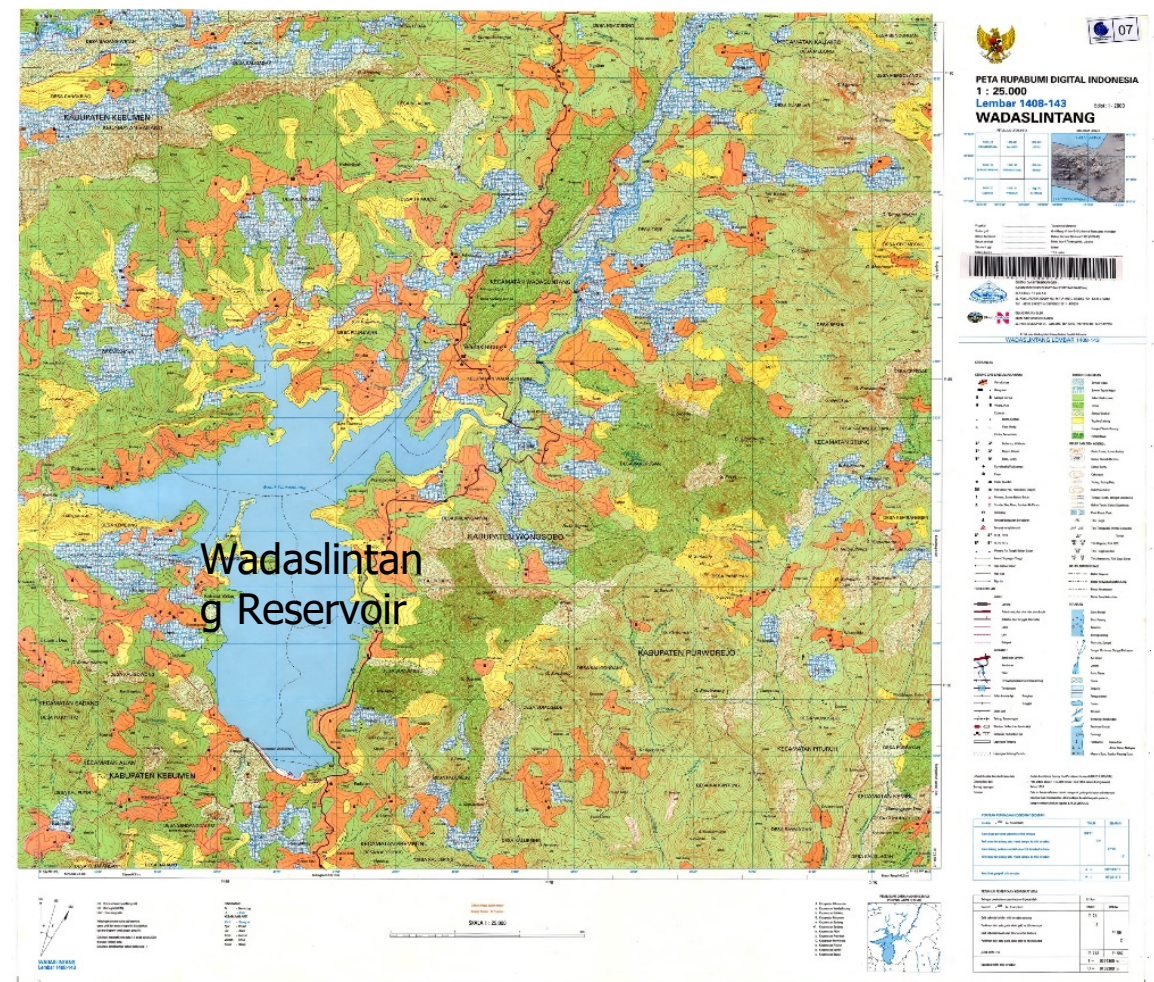

Fig. 1. Topographic map of the study area

Water sampling was carried out at ten stations (Figure 1 \& Table 1). Supporting parameters are physical-chemical factors which are measured in situ, including water temperature and $\mathrm{pH}$. Water samples are taken using a sterile water bottle sample with a volume of $500 \mathrm{ml}$ in surface water $(0 \mathrm{~m})$ which is then put in an ice box and then analyzed in a laboratory. The method for determining Coliform and Escherichia coli using the MPN (Most Probable Number) method refers to SNI-01-2332-1991. 
Table 1 Geographical position of the research station

\begin{tabular}{|c|c|c|c|}
\hline Stations & \multicolumn{2}{|c|}{ Geographical position } & Sites description \\
\hline St-1 & E $109^{0} 47^{\prime} 58.2 ”$ & S 07033'32.4”' & the mouth of The Tritis River to the reservoir body \\
\hline St-2 & E $109^{0} 47^{\prime} 55.3^{\prime \prime}$ & $\mathrm{S} 07^{0} 33^{\prime} 43.2^{\prime \prime}$ & the mouth of The Cengis River to the reservoir bodys \\
\hline St-3 & E $109^{\circ} 46^{\prime} 59.4 ”$ & $\mathrm{~S} 07^{0} 33^{\prime} 14.5^{\prime \prime}$ & the mouth of The Lancar River to the reservoir body \\
\hline St-4 & E $109^{\circ} 45^{\prime} 37.9^{\prime \prime}$ & S $07^{0} 34^{\prime} 14.0 \prime$ & the mouth of the Kumejing River to the reservoir body \\
\hline St-5 & E $109^{\circ} 47^{\prime} 16.1 ”$ & S 07034'14.3” & $\begin{array}{l}\text { meeting area of four rivers to the reservoir body (Cengis, } \\
\text { Tritis, Lancar and Kumejing Rivers) }\end{array}$ \\
\hline St-6 & E $109^{\circ} 47^{\prime} 05.9^{\prime \prime}$ & S $07^{0} 36^{\prime} 34.7^{\prime \prime}$ & the floating net cage area belongs to the community \\
\hline St-7 & E $109^{0} 47^{\prime} 19.0 ”$ & $\mathrm{~S} 07^{0} 35^{\prime} 20.5^{\prime \prime}$ & the floating net cage area belongs to a private company \\
\hline St-8 & E $109^{0} 46^{\prime} 48.8^{\prime \prime}$ & S $07^{0} 34^{\prime} 59.1^{\prime \prime}$ & Former floating net cage area \\
\hline St-9 & E $109^{0} 47^{\prime} 05.9^{\prime \prime}$ & S $07^{0} 36 ’ 34.7^{\prime \prime}$ & the tourist area \\
\hline St-10 & E $109^{\circ} 46^{\prime} 56.0^{\prime \prime}$ & S $07^{0} 36 ’ 29.0^{\prime \prime}$ & The reservoir outlet \\
\hline
\end{tabular}

Calculation of coliform and Escherichia coli bacterial density refers to SNI 2897-2008 with the formula:

Coliform density $=$ MPN table value $\mathrm{x} 1 /$ dilution center value

\section{Results}

Based on the results of measurements on all samples during the study showed that all positive samples contained total coliforms, with amounts far above the allowed quality standard according to the designation of classes 1 and 2 of Government Regulation of the Republic of Indonesia Number 82 of 2001.

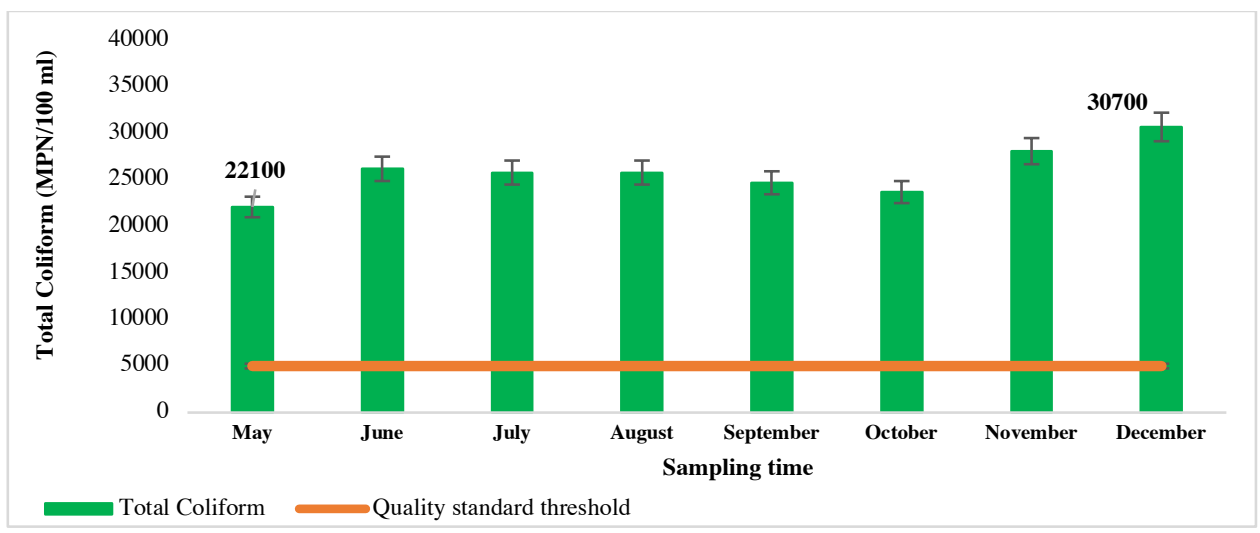

Fig. 2. Average of total coliform in Wadaslintang Reservoir is temporally and the quality standard threshold value

The measurement results also showed variations in total coliform concentrations during the study. The highest total coliform occurred in December with an average of $3.07 \times 104$ MPN / $100 \mathrm{ml}$ (Fig. 2), while the lowest total coliform was found in May of 2.2 x 104 MPN / $100 \mathrm{ml}$. 


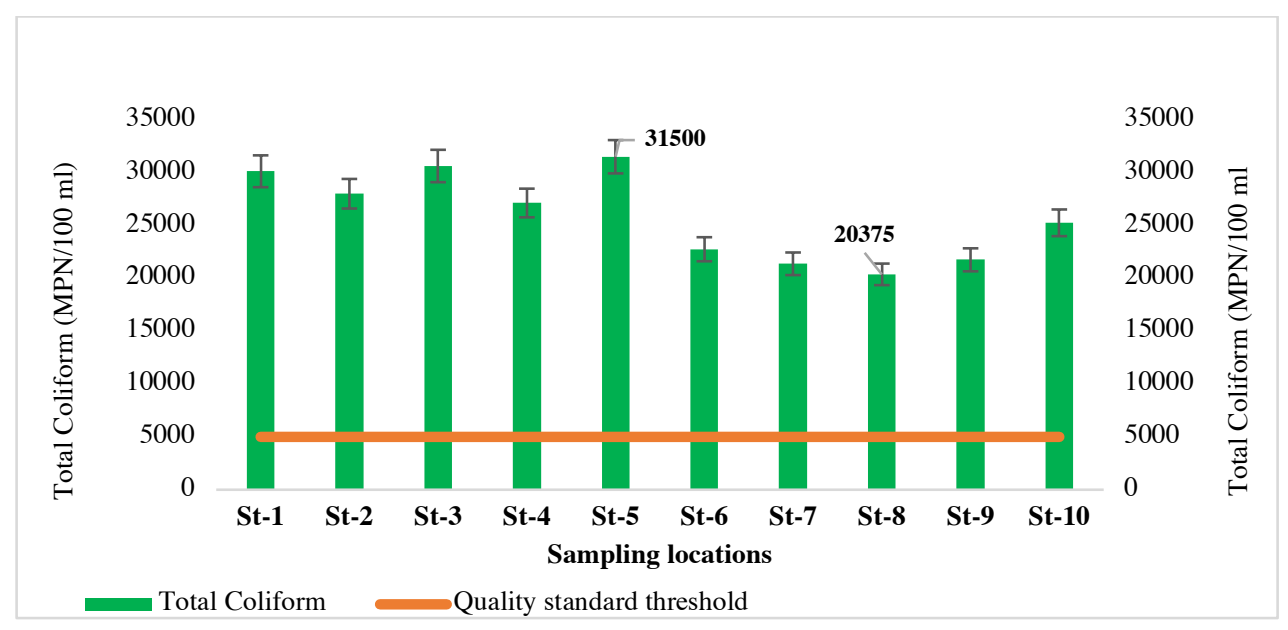

Fig. 3. Average of total coliform content is spatially in the Wadaslintang reservoir

Total coliform tends to be higher in the inlet area than in the reservoir area (Fig. 3), total coliform concentrations at stations 1-5 are higher than concentrations at stations 6-10. The highest concentrations are in the area of the confluence of four rivers that flow into the reservoir, while the lowest concentration is in the former floating net cage area.

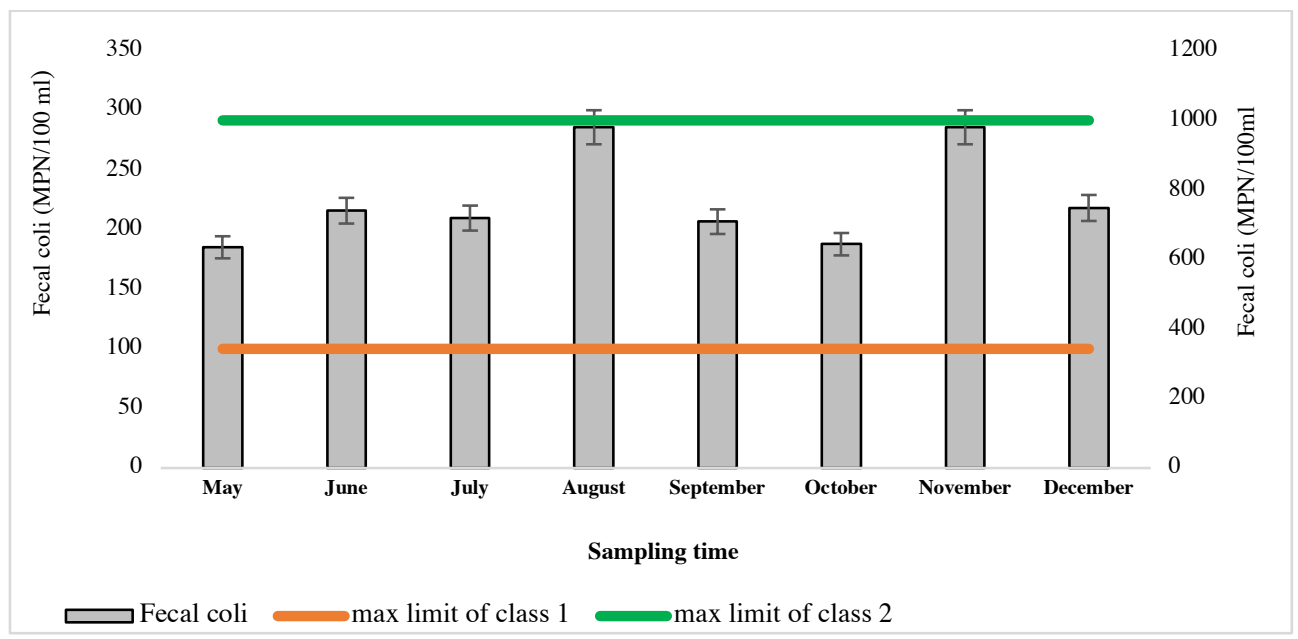

Fig. 4. Average of fecal coli in Wadaslintang Reservoir is temporally and the quality standard threshold value.

The results of coli fecal measurements during the study showed that all positive samples were polluted, with concentrations above the first-class quality standard threshold of the Republic of Indonesia Government Regulation No. 82 of 2001 (Fig. 4). The highest concentrations occurred in August and November each with an average concentration of 285.9 MPN / $100 \mathrm{ml}$. However, based on the designation of class 2 with a maximum value of fecal coli concentration of $1000 \mathrm{MPN} / 100 \mathrm{ml}$, all samples are still far below the quality standard threshold. However, based on the designation of class 2 with a maximum value of fecal coli concentration of $1000 \mathrm{MPN} / 100 \mathrm{ml}$, all samples are still far below the quality standard threshold. 


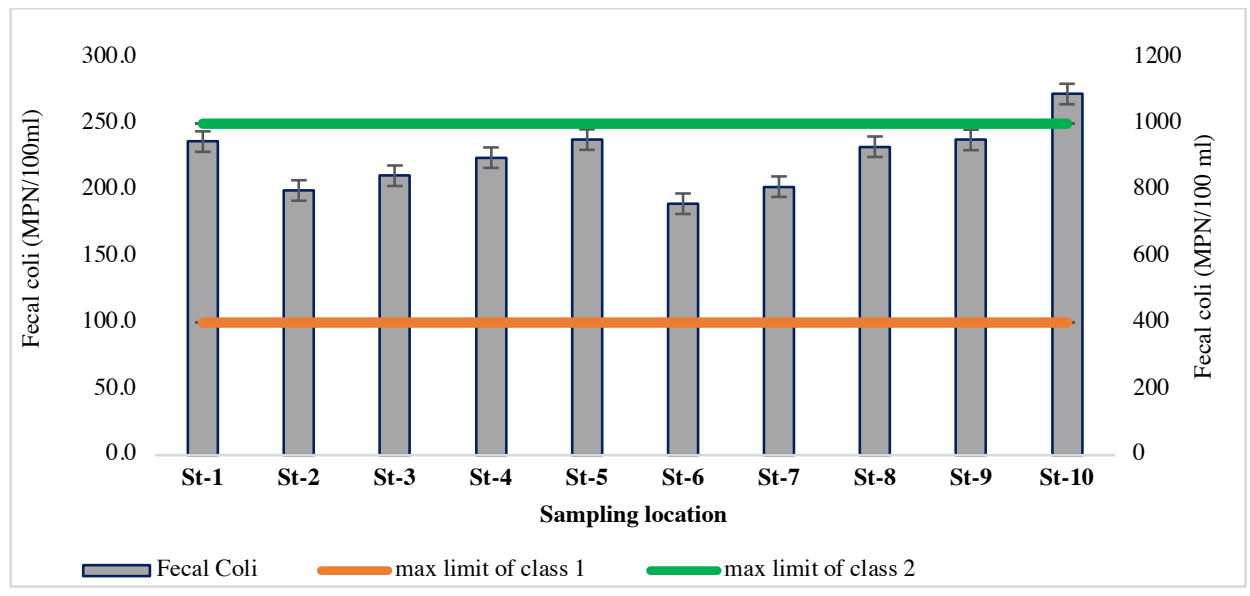

Fig. 5. Average of fecal coli content is spatially in the Wadaslintang reservoir

Fecal coli measurement results at all stations also show that all stations have been polluted based on the Republic of Indonesia Government Regulation class 1 designation with a maximum concentration of $100 \mathrm{MPN} / 100 \mathrm{ml}$ (Fig.5), whereas according to the second class designation with a maximum fecal coli value of $1000 \mathrm{MPN} / 100 \mathrm{ml}$, all stations are still far below the maximum value standard quality threshold. The results of water quality measurements which include water temperature and $\mathrm{pH}$ show the range as presented in Table 2.

Table 2. Range of physical-chemical factors of water during the study

\begin{tabular}{lllcccccc}
\hline \multicolumn{1}{c}{ Parameter } & \multicolumn{1}{c}{ May } & \multicolumn{1}{c}{ June } & \multicolumn{1}{c}{ July } & August & Sept & Oct & Nov & Dec \\
\hline Temperature (C) & $29.6-30.4$ & $29.7-30.6$ & $28.2-29.1$ & $28.1-29.4$ & $28-29.7$ & $28.5-29$ & $28-29.1$ & $28-30.4$ \\
$\mathrm{pH}$ & $6.7-6.8$ & $6.6-6.8$ & $6.5-6.7$ & $6.6-6.7$ & $6.4-6.6$ & $6.4-6.6$ & $6.5-6.6$ & $6.3-6.5$ \\
\hline
\end{tabular}

Water temperature during the study ranged from 28.0 - 30.6 C and there were no striking temperature differences during the study, the highest temperature occurred in December, which was $30.6{ }^{\circ} \mathrm{C}$. While the $\mathrm{pH}$ ranges between $6.4-6.8$, and there is no difference between the time of collection.

\section{Discussions}

Regulation of the Minister of Health of the Republic of Indonesia No.492 / MENKES / PER / IV / 2010 concerning drinking water quality requirements that must be met for the content of coliform bacteria and fecal coli in drinking water is $0 \mathrm{MPN} / 100 \mathrm{ml}$. According to Shafi et al., (2013) there are four categories based on coliform count and allotment for drinking water, bathing and swimming as well as other allotments. For category 1, the best levels are drinking water designation with MPN $=0$, category 2 and 3 for good and moderate levels are for bathing and swimming with MPN respectively 4 - 50, and 51 - 400, while category 4 is designation beyond those three things. Therefore, based on these criteria, all research stations are not suitable for use as raw water for drinking water, bathing and swimming.

Coliform is a bacterium that lives in the human digestive system [2], its presence in the waters does not mean that the waters have been polluted. However, if the total concentration of coliforms far exceeds the quality standard, then most likely the waters have been contaminated with fecal coli, because most of the total coliform consists of fecal coli bacteria. The high concentration of total coliform in the waters can be caused by the high concentration 
of organic matter originating from domestic waste and other antrophogenic activities. Besides changes in physical and chemical factors of waters such as temperature and $\mathrm{pH}$ also affect the increase and development of bacteria in the waters.

Water temperature is one parameter that can affect other parameters, an increase in water temperature will affect the metabolic rate of aquatic organisms. Temperature also affects the growth of E. coli, one of the bacteria that belongs to the total coliform group. E. coli will grow in the temperature range of $14{ }^{\circ} \mathrm{C}-45^{\circ} \mathrm{C}$, with an optimal temperature of $37^{\circ} \mathrm{C}$. This shows that the water conditions are suitable for bacterial growth and reproduction. In addition to temperature, $\mathrm{pH}$ is also one of the factors that influences the development of bacteria, in general bacteria will grow and develop at a low $\mathrm{pH}$ or below $\mathrm{pH} 7$ [1]. Based on the results of $\mathrm{pH}$ measurements, which range between 6-7, shows the waters are suitable for bacterial growth and development. Thus, to anticipate the impact caused by total coliform bacteria and fecal coli for the health of the body, it is necessary to do treatment first when consuming drinking water from reservoir water by heating it at temperatures over $100{ }^{\circ} \mathrm{C}$.

\section{Conclusions}

Based on the number of coliforms and fecal coli, the status of the Wadaslintang Reservoir has been polluted, referring to the first and second class quality standards of the Republic of Indonesia Government Regulation No. 82/2001, which has the potential to cause health problems if used as drinking water. It needs to be processed first by heating at temperatures over $100 \mathrm{oC}$ before use as drinking water.

\section{Acknowledgment}

The authors thank the anonymous reviewers for their contribution to this manuscript. The author also thanks the team of students who assisted in taking samples (Sutri Handayani, Diah Astira and Gina Oktariani).

\section{References}

1. L. Augustyn, A.M. Babula, J. Joniec, J. Stanek-Tarkowska, E. Hajduk, J. Kaniuczak. Microbiological indicators of the quality of river water, used for drinking water supply. Pols. J. of Env. Stu., 25 (2), 511-519 (2016).

2. A.D. Gronewold, M.E. Borsuk, R. L.Wolpert, K.H. Reckhow. An assessment of fecal indicator bacteria-based water quality standards (2008).

3. A.S. Piranti, D.R.U.S. Rahayu, G. Waluyo. Phosphorus Loading from Fish Farming Activities to Wadaslintang Reservoir Waters. In E3S Web of Conferences (Vol. 47, p. 04007. EDP Sciences 2018).

4. C. Rodrigues, \& M.Â. Cunha. Assessment of the microbiological quality of recreational waters: indicators and methods. Euro-Med. J. for Env. Int. 2 (1), 25. (2017).

5. S. Shafi, A.N. Kamili, M.A. Shah. M. A. Coliform bacterial estimation: A tool for assessing water quality of Manasbal Lake of Kashmir, Himalaya. Afc. J. of Mic. Resc, 7 (31), 3996-4000. (2013). 